\title{
In situ rumen degradation of amino acids from different feeds corrected for microbial contamination
}

\author{
Javier GonZÁLEZ ${ }^{\mathrm{a} *}$, Carmen CENTENO ${ }^{\mathrm{b}}$, Farida LAMRANI ${ }^{\mathrm{a} * *}$, \\ Carlos Alberto RoDRÍGUEZ \\ a Departamento de Producción Animal, Escuela Técnica Superior de Ingenieros Agrónomos, \\ Universidad Politécnica de Madrid, 28040 Madrid, Spain \\ b Consejo Superior de Investigaciones Científicas, Instituto de Nutrición y Bromatología, \\ 28040 Madrid, Spain
}

(Received 3 July 2000; accepted 9 July 2001)

\begin{abstract}
Variations of the amino acid profile produced by rumen actions were established for fish meal (FM), corn grain (CG), corn gluten feed (GF), dehydrated beet pulp (DBP), and lucerne hay (LH), using the nylon bag technique. The effects of degradation of soluble or insoluble proteins were measured by rumen incubations at $0 \mathrm{~h}$ (washout value) and $16 \mathrm{~h}$, respectively. Rumen incubations were performed on four cannulated wethers and the microbial contamination of incubated residues was corrected using a continuous ${ }^{15} \mathrm{~N}$-intraruminal infusion and solid associated bacteria isolates as the reference sample. The results showed that rumen degradation of both soluble and insoluble proteins produced changes in the amino acid profile, which were not uniform among feeds. Differences between feed and insoluble protein amino acid composition were limited for FM and DBP, important for GF and LH, and intermediate for CG. Differences between insoluble and undegraded protein amino acid composition were also limited for FM, GF, DBP, and LH and important in CG. The results showed that the amino acid profile in the undegraded protein and in the whole feed should be close for FM, DBP and LH. On the contrary, in CG, important variations are expected, since both solubility and degradability effects produced changes with the same tendency for most of the essential amino acids. In particular, our results showed a great decrease in the lysine content of the undegraded protein, which increases the lysine deficiency of this feed. This decrease of lysine was also evidenced in GF.
\end{abstract}

rumen degradation / amino acid profile / microbial contamination $/{ }^{15} \mathrm{~N}$

Résumé - Dégradation ruminale in situ des acides aminés de différents aliments, corrigée par la contamination microbienne. Les variations produites par les actions ruminales sur le profil des acides aminés de la farine de poisson (FP), du grain de maïs (GM), du gluten feed de maïs (GF), de la pulpe de betterave deshydratée (PBD) et du foin de luzerne (FL) ont été déterminées par la

* Correspondence and reprints

e-mail: jgonzalez@ pan.etsia.upm.es

** Present address: Institut Technique d'Élevage Bovin, Ovin et Caprin, BP 3, Baba Ali Bertonta, Algeria. 
méthode des sachets de nylon. Les effets de la dégradation des protéines solubles ou insolubles ont été mesurés en incubant dans le rumen les sachets contenant l'aliment à des temps de séjour de 0 (valeur de lavage) et 16 heures, respectivement. Les incubations ruminales ont été conduites sur quatre béliers porteurs de canules du rumen. Les résultats ont été corrigés en fonction de la contamination microbienne des résidus, moyennant l'infusion en continu de ${ }^{15} \mathrm{~N}$ dans le rumen et l'emploi comme référence d'un échantillon de bactéries adhérentes isolées du rumen. Les résultats montrent que la dégradation ruminale tant des protéines solubles que des protéines insolubles donne lieu à des changements du profil des acides aminés. Cependant ces changements ne sont pas uniformes parmi les aliments. La dégradation des protéines solubles a exercée un effet limité pour FP et PBD, alors qu'elle a été importante pour GF et FL et intermédiaire pour GM. Les effets de la dégradation des protéines insolubles ont été limités pour FP, GF, PBD et FL, mais importants pour GM. Les résultats ont montré que le profil des acides aminés des protéines non degradées est similaire à celui de la protéine d'origine pour FP, PBD et FL. Au contraire, pour GM on peut prévoir un important changement, puisque les variations produites par la dégradation des protéines solubles ou insolubles vont dans le même sens pour la plupart des acides aminés essentiels. En particulier, nos résultats montrent un fort appauvrisement de la teneur en lysine dans les protéines non degradées, ce qui accroît sa déficience dans l'aliment. Cette réduction de la teneur en lysine est démontrée aussi pour GF.

dégradation ruminale / profil des acides aminés / contamination microbienne / ${ }^{15} \mathrm{~N}$

\section{INTRODUCTION}

In order to improve modern protein evaluation systems for ruminants, more information on the animal's essential amino acid needs is necessary. In addition, more accurate estimates of the essential amino acids supplied to the animal are required. Therefore, an important step in the development of these systems is the knowledge of the amino acid composition of the feed undegraded protein. However, the effects of rumen fermentation on the amino acid profile of undegraded protein are not clear and subject to controversy [29, 35]. In addition, available data are scarce.

The nylon bag technique is the most usually employed method for the study of amino acid degradability and the variation of the amino acid profile after rumen fermentation. However, obtaining reliable values with this technique requires correction for microbial contamination $[6,36]$. Individual feeds are composed of a mixture of proteins, which have different amino acid compositions and resistances to rumen degradation. Therefore, the amino acid profile of the feeds will be changed by rumen microbial actions when both above conditions are presented. The most important differences of the resistance to rumen degradation are between soluble and insoluble proteins, since soluble proteins are generally assumed to be totally degraded. Therefore, the amino acid degradation of both protein fractions should be studied separately in order to obtain accurate conclusions. The aim of the present experiment was to determine the effect of washing and rumen incubation on the variation of the amino acid profile of different feedstuffs using ${ }^{15} \mathrm{~N}$ as a microbial marker in order to correct for microbial contamination of feed residues.

\section{MATERIALS AND METHODS}

\subsection{Experimental procedures}

Solubility and degradation of crude protein and individual amino acids were established by in sacco techniques. Tested samples were: fish meal (FM), corn grain (CG), corn gluten feed (GF), dehydrated beet pulp (DBP) and lucerne hay (LH).

Nylon bags (pore size $46 \mu \mathrm{m}$, reference 120T, Tissages Tissues Techniques, France) 
of $11 \times 7 \mathrm{~cm}$ (inner dimensions) made by heat-sealing (Preci-Pack P30N, Dover Pack S.A., Spain) were filled with approximately $3 \mathrm{~g}$ (air dry basis) of tested samples ground to pass a $2 \mathrm{~mm}$ screen. Duplicate bags were incubated for $16 \mathrm{~h}$ in the rumen of four rumen cannulated sheep $(63.1 \pm 0.90 \mathrm{~kg}$ LW) receiving a mixed diet of 2:1 chopped vetch-oat hay: pellet concentrate mixture. The chemical and raw composition of these feeds has been previously published [27]. This diet was offered at a level of $40 \mathrm{~g}$ $\mathrm{DM} \cdot \mathrm{kg}^{-1} \mathrm{LW}^{0.75}$ at six meals per day (every $4 \mathrm{~h}$ ) to raise rumen stability. Animals were kept in metabolism crates with free access to drinking water. All the bags were placed in the rumen just before the animals were offered their first morning meal $(9: 00 \mathrm{~h})$ and duplicates of each tested feed were made on different days. After collecting the bags from the rumen, they were washed with tap water and stored frozen. Once defrosted, the bags were washed three times for $5 \mathrm{~min}$ in a turbine washing machine. Then the bags were oven dried at $80^{\circ} \mathrm{C}$ for $48 \mathrm{~h}$, weighed and the residues were analysed for nitrogen (N) and amino acids. The mean values of these last results were obtained for each animal prior to statistical analysis. An additional set of three bags of each tested feed was reserved to establish the zero-time washout value by the above-cited washing procedure.

Microbial contamination of the rumen incubated residues was determined by labelling rumen micro-organisms with ${ }^{15} \mathrm{~N}$ by continuous intraruminal infusion of ammonium sulphate $\left(80 \mathrm{mg} \mathrm{N} \cdot \mathrm{d}^{-1}\right.$, 50 atoms \%) from five days before the start of the incubation trial to the end of it. At this moment, and before suppressing the infusion, representative samples of rumen content were obtained just before the first morning meal $(9: 00 \mathrm{~h})$ for solid associated bacteria (SAB) isolation. The methodology employed in obtaining these samples is described in detail by Rodríguez et al. [27]. Isolated SAB samples were lyophilised and analysed for DM, N, amino acids, and
$\mathrm{N}$ isotopic proportions $\left({ }^{15} \mathrm{~N} / \mathrm{N}\right)$. This last determination was also carried out for the bag residues.

Microbial N-content of the bag residues was determined assuming that the isotopic proportions of feed residual $\mathrm{N}$ were not altered by microbial actions. The microbial contribution of DM and N-content of the nylon bag residues was determined as follows:

$$
\begin{aligned}
& { }^{15} \mathrm{~N} \text { abundance } \\
& \text { in residue }-{ }^{15} \mathrm{~N} \\
& \text { abundance in feed } \\
& \text { Microbial N\% }=\frac{}{15} \times 100 \\
& { }^{15} \mathrm{~N} \text { abundance } \\
& \text { in } \mathrm{SAB}-{ }^{15} \mathrm{~N} \\
& \text { abundance in feed }
\end{aligned}
$$

Microbial DM $\%=$ Microbial $\mathrm{N} \% \times(\% \mathrm{~N}$ in residue $/ \% \mathrm{~N}$ in $\mathrm{SAB}$ ).

The microbial content of the individual amino acids in the residues was calculated from this last value and from their concentration (on a DM basis) in SAB. The ${ }^{15} \mathrm{~N}$ abundance in tested feeds was determined on the zero incubation residues because only the insoluble fraction is subjected to microbial contamination.

\subsection{Analytical}

In the tested feeds, $\mathrm{CP}(\mathrm{N} \times 6.25)$ was estimated by the Kjeldahl procedure [1]. Nitrogen and ${ }^{15} \mathrm{~N}$ enrichment of the nylon bag residues and microbial samples were analysed respectively by the Kjeldhal method and isotope-ratio mass spectrometry. The mass spectrometer (VG Prism II; VS Isotech, Ches., UK) was linked in series to a Dumas-style N analyser EA 1108 (Carlo Erba Instruments, Milan, Italy). Amino acids were determined in bacteria, tested feeds and nylon bag residues by reverse phase high pressure liquid chromatography after previous hydrolysis with hydrochloric acid $(6 \mathrm{~N})$ under a nitrogen atmosphere and derivatisation, according to the technique of Jones et al. [11], but using a fluorescence 
detector only. Proline, cystine and tryptophan were not determined due to technical limitations. The values of methionine were underevaluated since this amino acid is somewhat labile when proteins are hydrolysed in acid in the presence of carbohydrates $[24,31]$. The importance of this underevaluation for the different samples is discussed later.

\subsection{Statistical analysis}

For each feed, the comparisons between the individual amino acid content (expressed as $\%$ of the measured amino acids) in the residues at zero time and at $16 \mathrm{~h}$ of incubation were performed by analysis of variance as a completely randomised design, whereas the effect of washing on the amino acid pattern was established by a $t$-test on the differences between the zero time values and those determined for the original feed. This last test was not performed for methionine in vegetable feeds, since the losses produced during hydrolysis should have been different in both sample types as a consequence of the disappearance of soluble carbohydrates in zero time samples. Significant effects were considered for $P<0.05$. All analyses were performed using the statistical software SAS v 6.12 [30].

\section{RESULTS}

Some characteristics of chemical composition and degradation of the nitrogenous compounds of tested feeds, including the CP solubility (zero value), the disappearance of insoluble $\mathrm{CP}$ after $16 \mathrm{~h}$ of rumen incubation, and the microbial contamination of feed rumen incubated residues are recorded in Table I. These former values were very low for FM (4.1 mg microbial $\mathrm{N} \cdot \mathrm{g}^{-1} \mathrm{~N}$ ), high for CG, DBP, and LH (from 206 to $221 \mathrm{mg}$ microbial $\mathrm{N} \cdot \mathrm{g}^{-1} \mathrm{~N}$ ), and intermediate for GF $\left(94.1 \mathrm{mg}\right.$ microbial $\mathrm{N} \cdot \mathrm{g}^{-1}$ N)

The amino acid proportions of the different tested feeds are given in Table II, together with those of SAB samples employed to correct the values of amino acid disappearance after $16 \mathrm{~h}$ of rumen incubation. Mean values of CP content and total analysed amino acid concentration in SAB samples were $440 \mathrm{~g} \cdot \mathrm{kg}^{-1} \mathrm{DM}$ and $81.8 \mathrm{~g} \cdot 16 \mathrm{~g}^{-1} \mathrm{~N}$, respectively.

The variations produced by washing and rumen degradation at $16 \mathrm{~h}$ on the amino acid profile of the different tested feeds are given in Figures 1 to 5.

The results obtained for FM (Fig. 1) did not show any effects on the amino acid profile, except for methionine, whose proportion increased and decreased respectively

Table I. Chemical composition and degradation characteristics of nitrogenous compounds of the tested feeds.

\begin{tabular}{lrrrrr}
\hline Item & FM & CG & GF & DBP & LH \\
\hline Neutral detergent fibre $\left(\mathrm{g} \cdot \mathrm{kg}^{-1} \mathrm{DM}\right)$ & - & 142 & 463 & 491 & 391 \\
Acid detergent lignin $\left(\mathrm{g} \cdot \mathrm{kg}^{-1} \mathrm{DM}\right)$ & - & 20.4 & 30.1 & 42.7 & 70.9 \\
Crude protein $(\mathrm{CP})\left(\mathrm{g} \cdot \mathrm{kg}^{-1} \mathrm{DM}\right)$ & 657 & 91.2 & 221 & 110 & 243 \\
Total analysed amino acids $\left(\mathrm{g} \mathrm{AA} \cdot 16 \mathrm{~g}^{-1} \mathrm{~N}\right)$ & 91.5 & 80.0 & 77.7 & 72.5 & 67.4 \\
CP solubility $(\%)$ & 30.5 & 15.7 & 35.8 & 17.7 & 43.0 \\
Degradation of insoluble CP $(\%)^{1}$ & 6.5 & 54.1 & 51.4 & 65.4 & 78.9 \\
Microbial contamination $\left(\mathrm{mg} \mathrm{microbial} \mathrm{N} \cdot \mathrm{g}^{-1} \mathrm{~N}\right)$ & 4.1 & 220 & 94.1 & 221 & 206
\end{tabular}

FM: fish meal, CG: corn grain, GF: gluten feed, DBP: dehydrated beet pulp, LH: lucerne hay.

${ }^{1}$ Measured at $16 \mathrm{~h}$ of rumen incubation. 
with the process of washing and rumen incubation. Nevertheless, these variations were moderate (12\% and $16 \%$, respectively).
The significant changes in the amino acid profile of CG induced by washing (Fig. 2) were limited for the increases observed for

Table II. Amino acid proportions ( $\mathrm{g} \cdot 100 \mathrm{~g}^{-1}$ of analysed AA) of tested feeds and of solid associated bacteria $(\mathrm{SAB})$ of the rumen.

\begin{tabular}{|c|c|c|c|c|c|c|}
\hline Item & $\mathrm{FM}$ & $\mathrm{CG}$ & GF & DBP & LH & SAB \\
\hline Arginine & 6.29 & 5.73 & 6.78 & 5.04 & 5.94 & 4.28 \\
\hline Histidine & 2.55 & 2.53 & 2.06 & 3.25 & 1.69 & 1.32 \\
\hline Isoleucine & 4.95 & 3.76 & 3.98 & 4.58 & 5.41 & 6.53 \\
\hline Leucine & 8.36 & 14.00 & 10.10 & 7.94 & 9.54 & 7.99 \\
\hline Lysine & 7.76 & 3.53 & 3.85 & 6.25 & 6.13 & 7.99 \\
\hline Methionine & 2.87 & 0.92 & 1.53 & 0.71 & 1.15 & 2.20 \\
\hline Phenylalanine & 4.63 & 5.53 & 4.98 & 4.89 & 6.30 & 5.62 \\
\hline Threonine & 6.59 & 5.44 & 7.88 & 6.66 & 6.88 & 5.85 \\
\hline Valine & 5.51 & 4.93 & 5.81 & 6.99 & 6.65 & 5.70 \\
\hline Alanine & 7.10 & 7.77 & 7.18 & 6.36 & 6.65 & 6.15 \\
\hline Aspartic acid & 10.50 & 6.65 & 7.98 & 10.80 & 13.40 & 14.30 \\
\hline Glutamic acid & 16.20 & 25.20 & 21.40 & 15.40 & 15.50 & 16.40 \\
\hline Glycine & 6.77 & 4.05 & 6.20 & 6.45 & 5.34 & 5.21 \\
\hline Serine & 6.01 & 5.17 & 6.10 & 8.66 & 5.00 & 5.20 \\
\hline Tyrosine & 3.94 & 4.81 & 4.21 & 6.03 & 4.39 & 5.30 \\
\hline
\end{tabular}

For abbreviations see Table I.

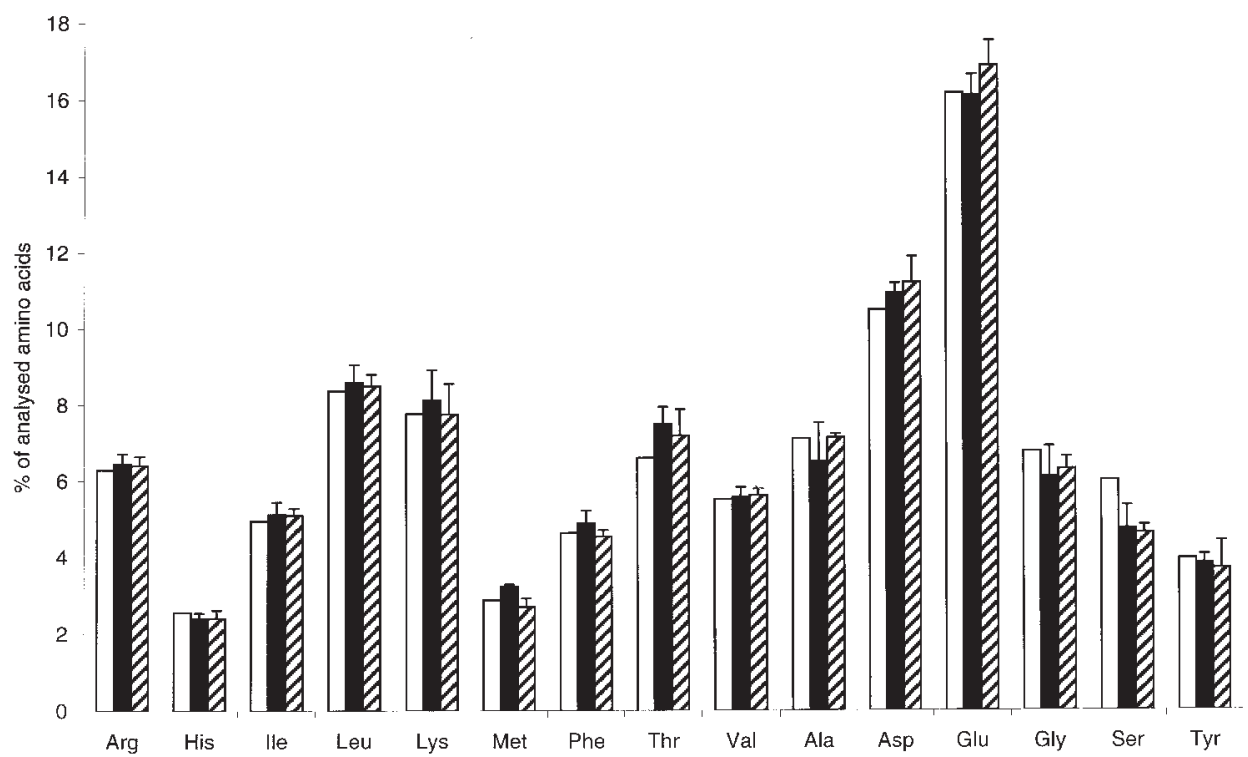

Figure 1. Amino acid profile (\% of analysed amino acids) of fish meal ( $\square$ original fraction) and its residues remaining after washing ( $\mathbf{\square}$ insoluble fraction) or after sixteen hours of rumen incubation ( $\square$ non degraded fraction). Values are means \pm SD. 


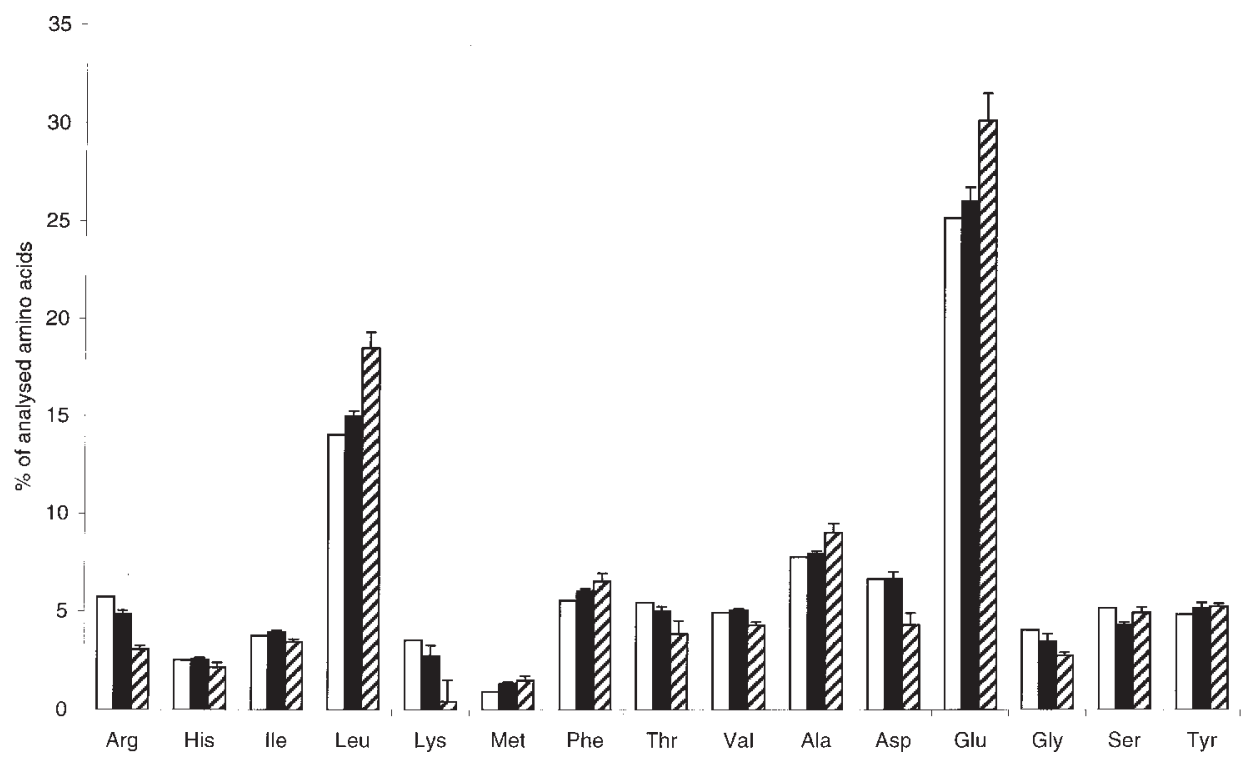

Figure 2. Amino acid profile (\% of analysed amino acids) of corn grain ( $\square$ original fraction) and its residues remaining after washing ( $\boldsymbol{\square}$ insoluble fraction) or after sixteen hours of rumen incubation ( $\square$ non degraded fraction). Values are means \pm SD.

phenylalanine, leucine, and isoleucine (between 5 and $9 \%$ ), and moderate for the decreases recorded for arginine and serine ( 15.5 and $16.8 \%$, respectively). Conversely, the effects of degradation of insoluble proteins were very important, affecting all analysed amino acids except methionine, phenylalanine, and tyrosine. Amongst the essential amino acids, these variations were especially important for lysine (reduction of $84.6 \%$ ) and leucine (increase of $23.4 \%$ ).

The amino acid profile of GF (Fig. 3), conversely to that observed for CG, was more intensely varied by washing than by rumen incubation ( 8 and 3 amino acids significantly affected, respectively). Amongst the essential amino acids, important variations associated with washing were recorded for histidine (an increase of 37.4\%) and threonine (a decrease of $36 \%$ ), while those observed for valine and lysine were low (6.5 and $5.5 \%$, respectively). Amongst the nonessential amino acids, significant effects were observed for aspartic acid, glutamic acid, glycine, and serine. As a consequence of insoluble protein degradation, the proportion of lysine was reduced again $(15.4 \%)$ and that of leucine and alanine increased (11.6 and $9.1 \%$, respectively).

The variations in the amino acid proportions of DBP (Fig. 4) were limited. Washing effects included an increase for isoleucine $(9.2 \%)$ and a decrease for serine $(19.9 \%)$. The only effect of rumen incubation was a decrease (13.8\%) for threonine.

In LH (Fig. 5), although the significant variations due to washing affected 8 amino acids, these changes were only important for histidine (increase of 30\%), whereas they were moderate (between 12 and 16\%) for arginine and aspartic acid and small (less than $10 \%$ ) for tyrosine, serine, alanine, lysine and glycine. On the contrary, rumen incubation did not show any effects, except for an increase (13.9\%) in the proportion of glycine. 


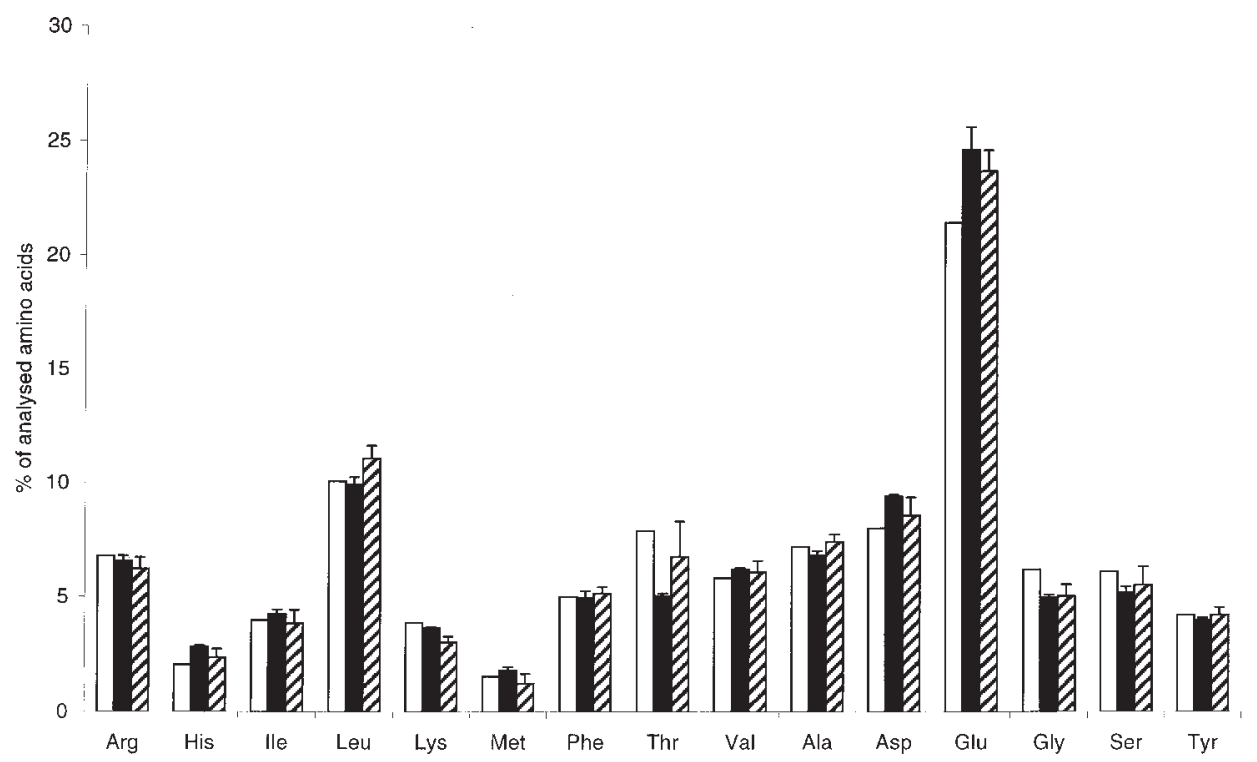

Figure 3. Amino acid profile (\% of analysed amino acids) of corn gluten feed ( $\square$ original fraction) and its residues remaining after washing ( $\boldsymbol{\square}$ insoluble fraction) or after sixteen hours of rumen incubation ( non degraded fraction). Values are means \pm SD.

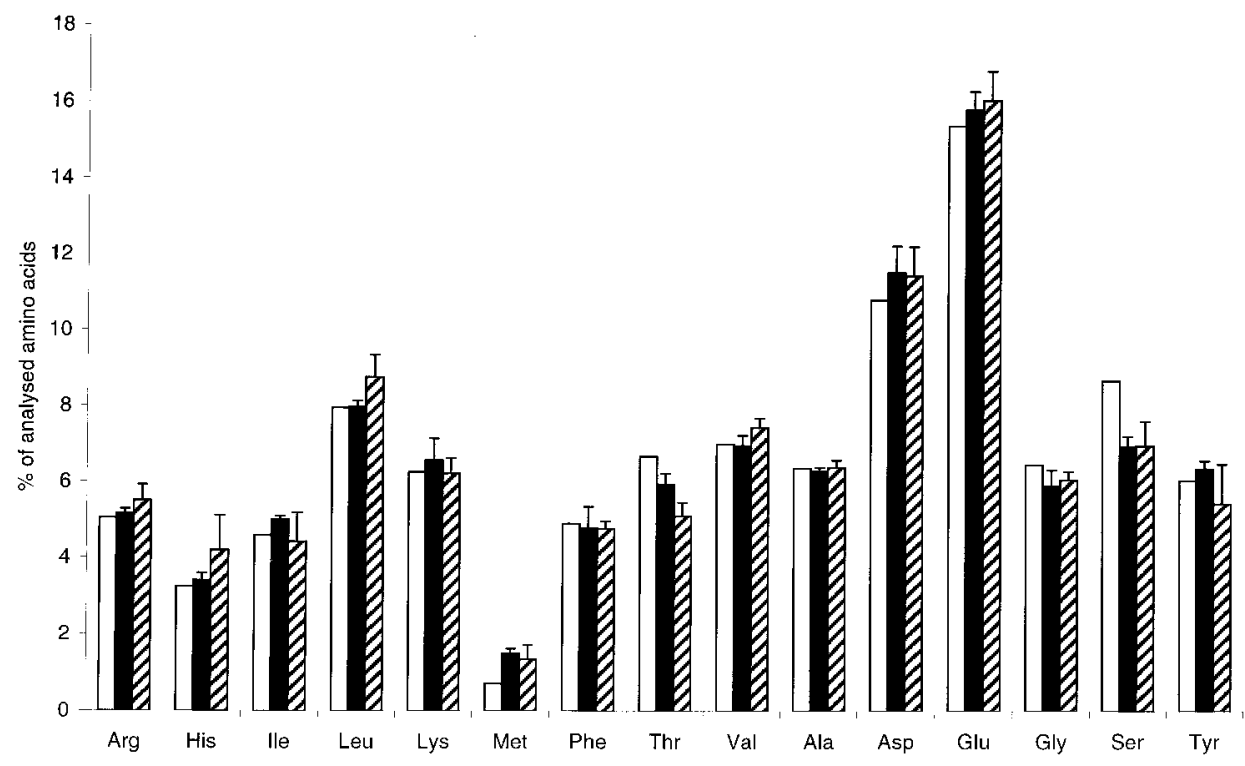

Figure 4. Amino acid profile (\% of analysed amino acids) of dehydrated beet pulp ( $\square$ original fraction) and its residues remaining after washing ( $\boldsymbol{\square}$ insoluble fraction) or after sixteen hours of rumen incubation ( $\square$ non degraded fraction). Values are means \pm SD. 


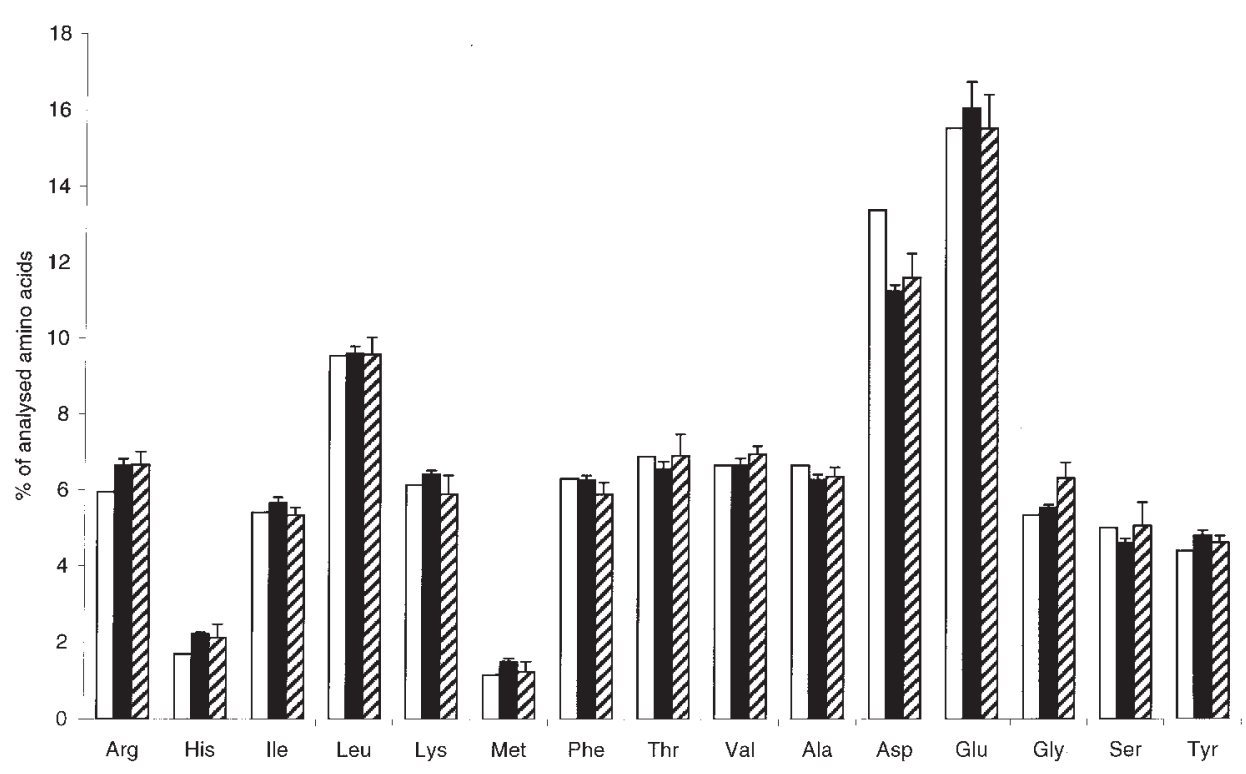

Figure 5. Amino acid profile (\% of analysed amino acids) of lucerne hay ( $\square$ original fraction) and its residues remaining after washing ( $\boldsymbol{\square}$ insoluble fraction) or after sixteen hours of rumen incubation ( $\boldsymbol{\nabla}$ non degraded fraction). Values are means \pm SD

\section{DISCUSSION}

The concentrations of the total analysed amino acids of tested feeds were in good agreement with the results of different feed tables [3, 7], except for that of LH, which was slightly lower (about 15\%, as mean). Nevertheless, these reference values only represent mean values and their variability is not indicated in the different tables. The proportions of the individual amino acids also agree, in general, with the values of these tables. An exception was the low values observed for methionine, especially in DBP, but also in CG, LH and GF. The underevaluation of methionine concentrations in DBP and CG was also evidenced by obtaining negative disappearances at zero time. The values of methionine obtained after direct hydrolysis lead to an underestimation in relation to the recoveries corresponding to its oxidation with performic acid to its sulfone [38]. Spindler et al. [32] determined the methionine losses after direct hydrolysis (in similar conditions to those of this experiment) in relation to the recoveries obtained after an oxidative pre-treatment. Despite the presence of a nitrogen atmosphere, these losses were important, but variable, in rich-carbohydrate feeds (mean losses of 22.2 and $11.7 \%$ for 12 and 14 samples of wheat and corn, respectively), but low for animal protein rich feeds such as meat and bone meal (mean losses of 1.9\% for 18 samples). A moderate loss of $7 \%$ was also observed by these authors for a fish meal sample. Therefore, the present results for methionine are not totally conclusive. However, if constant losses of methionine are assumed, the importance of this error is reduced by expressing the results as variations of the amino acid profile. Since similar losses could not be assumed between the whole and the insoluble fraction of vegetable feeds - as a consequence of carbohydrate solubilisation - the statistical 
comparison was avoided for these feeds as previously indicated. Another possible deviation in relation to the values of the feed tables was the high proportions of threonine recorded for FM and GF.

The CP content of SAB was close to the mean value given in the review of Clark et al. [4] for rumen bacteria. Also, the proportions of individual amino acids are in acceptable agreement with previous results on this microbial population $[12,13]$.

As previously observed $[9,16,34]$, the microbial contamination of FM was very low. This fact, together with the higher concentrations of amino acids in crude protein in FM than in SAB, showed that amino acid corrections from microbial contamination were practically null for this feed. On the contrary, microbial contamination attained high levels in LH, DBP, and CG. High values of contamination are usually observed in fibrous feeds [2, 17, 19, 25] and also in corn grain [2, 25, 34, 37]. Microbial colonisation of feed particles should be conditioned by the content of insoluble materials resistant to degradation, which, in vegetal feeds, are mainly the cell wall components or, in corn, the corneus starch [26]. However, microbial $\mathrm{N}$ contamination is also dependent on feed $\mathrm{N}$ content $[14,26]$ because its dilution effects on the microbial $\mathrm{N}$ proportion of the bag residues. Both factors also justify the moderate contamination level observed for a low fibre feed with an intermediate protein content such as GF. Since differences in the amino acid profile between SAB and these feeds are important (Tab. II), the lack of correction for microbial contamination should lead to an important bias of the results.

The low variations observed for the amino acid profile of FM show a high homogeneity in the amino acid composition of the soluble and insoluble proteins and are in logical agreement with the low degradation of its $\mathrm{CP}$ insoluble fraction $(6.5 \%$ at $16 \mathrm{~h}$ of incubation). The low effective degradability of the insoluble proteins of this feed $(6.8 \%$ of total insoluble CP for this same sample [9]), and the moderate and opposed variations observed for methionine allow to infer that the amino acid profile of the undegraded protein should be very similar to that of the whole feed. The results of Susmel et al. [33] and Cozzi et al. [5] showed higher variations than the present results. Nevertheless, the level of agreement between both of these data sources was also low.

The effects due to solubility observed for CG were similar to those showed using Burroughs buffers by Mac Gregor et al. [15], although, the variations observed by these authors were stronger than those in our results, especially for arginine and lysine. According to Reiners et al. [23] albumins and globulins (soluble proteins) and gluteins and zeine (insoluble proteins) represent respectively: $8,9,40$ and $39 \%$ of total protein of corn grain, which is in good agreement with our result of soluble CP. Predictable variations from these proportions and from the differences in the amino acid profile of albumins and globulins [20] and gluteins and zeine [21] support, in general, our present results. Thus, the more important differences between soluble and insoluble proteins were observed for leucine, methionine, arginine, phenylalanine, lysine and glutamic acid coinciding with most of the significant differences observed. Differences in the amino acid profiles of gluteins and zeine [21] also help to explain the degradation effects observed on insoluble proteins. According to the high resistance to the degradation of zeine [10] and to the degradation level observed at $16 \mathrm{~h}$ of incubation, the residual protein should be mainly composed of zeine as shown by the high correlation $(r=0.933 ; P<0.001)$ found between the present amino acid profile and that of zeine [21]. The most important variations between gluteins and zeine [21] are for glutamic acid, glycine, arginine and, especially for leucine and lysine, which is in agreement with our results. The effects of degradation of soluble and insoluble proteins showed, in general (for 9 amino acids), the 
same tendency. Therefore, the amino acid profile of undegraded protein should differ extensively to that of corn grain. For lysine, usually considered as the more limiting amino acid in corn, our present results showed an important reduction in the undegraded protein. This fact agrees with the revision of Rulquin [28] showing that positive effects of postrumen lysine supplementation are especially important with corn rich diets.

The effects due to the degradation of soluble proteins for GF were more extended and intense than in $\mathrm{CG}$, which is in agreement with its higher CP solubility value (Tab. I) associated with the addition of "solubles" to this by-product. Amongst essential amino acids, the effects of insoluble protein degradation were only recorded for those (lysine and leucine) that showed the more strong variation in CG. The evolution of lysine proportions in this feed support the impoverishment in this amino acid of the protein from this origin as a consequence of rumen digestion. Our present results also support the observation of Van Straalen et al. [35] that the amino acid profile of GF is more affected by washing than by rumen incubation.

Washing effects on essential amino acid proportions of DBP were limited. The variations observed for isoleucine agree with data of Van Straalen et al. [35], although these authors also observed important variations for other amino acids. However, the DBP sample employed by these authors included an important addition of molasses and therefore, its protein solubility was higher than in the present sample (zero time values: $50 \%$ and $18.8 \%$ respectively). Beet pulp is commonly added with molasses or vinasses, which had an important effect on protein solubility. Thus, Pereira [22] on 10 samples of DBP observed a range of variation of the soluble CP fraction from 7 to $50 \%$. Since the amino acid compositions of molasses or vinasses are very different from that of beet pulp [18], the effects of protein solubility on the amino acid profile of the undegraded protein from DBP will depend on the possible additions of these by-products. On the contrary, the results obtained at $16 \mathrm{~h}$ of incubation support the observation of Van Straalen et al. [35] that the degradation of insoluble proteins has little effect on the amino acid profile of this feed.

The results of LH supported observations that were similar to those deduced for DBP: there was a low variation of the amino acid profile as a consequence of the degradation of soluble or insoluble proteins and, for both protein types, there was a higher influence of the soluble protein degradation. Therefore, our present results infer that the amino acid profile of the undegraded protein could be similar to that of whole hay, although some increased in histidine. Our results agree with those of Erasmus et al. [8]. Nevertheless, these authors did not find any effect for histidine and, on the contrary, they observed an increase in the proportion of phenylalanine, which was unaffected in the present sample.

Considering that the degradation of individual amino acids should mainly depend on the degradation of the proteins in which they are included, the very low variation observed for the degradation of insoluble proteins as in LH as in DBP trend to indicate that the amino acid composition of insoluble proteins and/or their degradation susceptibility should be relatively uniform in feeds composed of vegetative tissues.

As a consequence of the scarce available data and of the discrepancy between these data, Rulquin and Vérité [29] have proposed to consider the feed amino acid profiles as a first guide to estimating the amino acid profiles of the undegraded protein. Our present results show that the extent of variations in the amino acid profile differs according to feeds. Consequently, the above approach will not be valid for some feeds, especially for those with proteins with a high heterogeneity of amino acid composition and rumen degradation resistance. The use of 
the amino acid profile of insoluble proteins for this purpose should be a better approach for feeds with an important fraction of soluble proteins (such as by-products added with "solubles").

\section{ACKNOWLEDGEMENTS}

This work has been supported by the CICYT funded Projects AGF 93-0549-CO2-01 and AGF 98-0842. Analyses of ${ }^{15} \mathrm{~N}$ isotopic relation were performed at the Servicio Interdepartamental de Investigación, Universidad Autónoma de Madrid.

\section{REFERENCES}

[1] AOAC, Official Methods of Analysis (15th ed.), Association of Official Analytical Chemists, Arlington, VA, 1990.

[2] Bernard L., Marvalin O., Yang W., Poncet C., Colonisation bactérienne de différents types d'aliments incubés in sacco dans le rumen conséquences pour l'estimation de la dégradabilité de l'azote, Reprod. Nutr. Dev. 28 (Suppl. 1) (1988) 105-106.

[3] Centraal Veevoederbureau, Veevoedertabel (Dutch Feeding Tables), Centraal Veevoederbureau, Lelystad, 1994.

[4] Clark J.H., Klusmeyer T.H., Cameron M.R., Microbial protein synthesis and flows of nitrogen fractions to the duodenum of dairy cows, J. Dairy Sci. 75 (1992) 2304-2323.

[5] Cozzi G., Andrighetto I., Berzaghi P., In situ ruminal disappearance of essential amino acids in protein feedstuffs, J. Dairy Sci. 78 (1995) 161-171.

[6] Croocker B.A., Clark J.H., Shanks R.D., Fahey G.J. Jr., Effects of ruminal exposure on the amino acid profile of feeds, Can. J. Anim. Sci. 67 (1987) 1143-1148.

[7] Degussa, The amino acid composition of feedstuffs (4th ed.), Degussa Feed Additives, 1996.

[8] Erasmus L.J., Botha P.M., Cruywagen C.W. Meissner H.H., Amino acid profile and intestinal digestibility in dairy cows of rumenundegradable protein from various feedstuffs, J. Dairy Sci. 77 (1994) 541-551.

[9] González J., Rodríguez C.A., Andrés S.G., Alvir M.R., Rumen degradability and microbial contamination of fish meal and meat meal measured by the in situ technique, Anim. Feed Sci. Technol. 73 (1998) 71-84.

[10] INRA, Alimentation des ruminants, Institut National de la Recherche Agronomique, Paris, 1978.
[11] Jones B.R., Pääbo S., Stein S., Amino acid analysis and enzymatic sequence determination of peptides by an improved ophthaldialdehyde precolumn labelling procedure, J. Liq. Chromatogr. 4 (1981) 565-586.

[12] Lallès J.P., Poncet C., Toullec R., Compositon en acides aminés des bactéries libres et des bactéries fixées aux particules alimentaires du réticulo-rumen du veau sevré et du mouton recevant différentes rations, Ann. Zootech. 41 (1992) 75-76.

[13] Martin C., Bernard L., Michalet-Doreau B., Influence of sampling time and diet on amino acid composition of protozoal and bacterial fractions from bovine ruminal contents, J. Anim. Sci. 74 (1996) 1157-1163.

[14] Michalet-Doreau B., Nozière P., Intérêts et limites de l'utilisation de la technique des sachets pour l'étude de la digestion ruminale, INRA Prod. Anim. 12 (1999) 195-206.

[15] MacGregor C.A., Sniffen C.J., Hoover W.H., Amino acid profiles of total and soluble protein in feedstuffs commonly fed to ruminants, J. Dairy Sci. 61 (1978) 566-573.

[16] Mathers J.C., Aitchison E.M., Direct estimation of the extent of contamination of food residues by microbial matter after incubation within synthetic fibre bags in the rumen, J. Agric. Sci. 96 (1981) 691-693.

[17] Nocek J.E., Grant A.L., Characterization of in situ nitrogen and fiber digestion and bacterial nitrogen contamination of hay crop forages preserved at different dry matter percentages, J. Anim. Sci. 64 (1987) 552-564.

[18] Novus, raw material compendium, Second Edition, Novus International, INC, 1994.

[19] Ould-Bah M.Y., Michalet-Doreau B., Jamot J., Contamination bactérienne des résidus alimentaires des sachets incubés dans le rumen : utilisation du « Stomacher » pour la réduire et conséquences sur la mesure de la dégradabilité ruminale de l'azote, Reprod. Nutr. Dev. 28 (Suppl. 1) (1988) 107-108.

[20] Paulis J.W., Wall J.S., Albumins and globulins in extracts of corn grain parts, Cereal Chem. 46 (1969) 263-273.

[21] Paulis J.W., James C, Wall J.S., Comparison of glutelin protein in normal and high-lysine corn endosperm, J. Agric. Food Chem. 17 (1969) 1301-1305.

[22] Pereira J.C., Degradación ruminal de diversos subproductos agroindustriales, Tesis Doctoral, Escuela Técnica Superior de Ingenieros Agrónomos, Universidad Politécnica, Madrid, 1992.

[23] Reiners R.A., Wall J.S., Inglett G.E., Corn proteins: potential for their industrial use, in: Pomeranz Y. (Ed.), Industrial use of Cereals, American Association of Cereal Chemist, Inc. St. Paul, MN, 1973, pp. 285-302. 
[24] Robel E., Effect of the volume of $\mathrm{HCl}$ in minimizing amino acid losses when carbohydratecontaining samples are hydrolized, Poult. Sci. 52 (1973) 604-607.

[25] Rodríguez C.A., Estudio de la colonización microbiana de los alimentos en el rumen. Implicaciones sobre la estimación de la degradabilidad ruminal de las materias nitrogenadas mediante técnicas in situ, Tesis Doctoral, Escuela Técnica Superior de Ingenieros Agrónomos, Universidad Politécnica, Madrid, 1996.

[26] Rodríguez C.A., González J., Alvir M.R., Repetto J.L., Microbial nitrogen contamination of in sacco ruminal incubated feed, in: Lobley G.E., White A., MacRae C. (Eds.), Protein metabolism and nutrition, Wageningen pers, Wageningen, 1999, p. 68

[27] Rodríguez C.A., González J., Alvir M.R., Repetto J.L., Centeno C., Lamrani F., Composition of bacteria harvested from the liquid and solid fractions of the rumen of sheep as influenced by feed intake, Brit. J. Nutr. 84 (2000) 369-376.

[28] Rulquin H., Intérêts et limites d'un apport de méthionine et de lysine dans l'alimentation des vaches laitières, INRA Prod. Anim. 5 (1992) 29-36.

[29] Rulquin H., Vérité R., Amino acid nutrition of dairy cows: productive effects and animal requirements, in: Garnsworthy P.C., Cole D.J.A (Eds.), Recent Advances in Animal Nutrition, Nottingham University Press, Nottingham, 1993, pp. 55-77.

[30] SAS, SAS/STAT User's Guide (version 6, 4th ed.), Statistical Analysis System Institute Inc. (Ed.), Cary, NC, 1990.

[31] Smith P., Ambrose M.E., Knobl G.M., Possible interference of fats, carbohydrates and salts in amino acid determinations in fish meals, fish protein concentrates and mixed animal feeds, J. Agric. Food Chem. 13 (1965) 266-268.

[32] Spindler M., Stadler R., Tanner H., Amino acid analysis of feedstuffs: determination of methionine and cystine after oxidation with performic acid and hydrolysis, J. Agric. Food Chem. 32 (1984) 1366-1371.

[33] Susmel P., Stefanon B., Mills C.R., Candido M., Change in amino acid composition of different protein sources after rumen incubation, Anim. Prod. 49 (1989) 375-383.

[34] Valadares Filho S.C., Cohelo da Silva, J.F., Sant'anna R., Diniz Valadalares R.F., Cohelo E.H., Contaminacao bacteriana em residuos da incubacao ruminal de alguns alimentos em sacos de nailon, Rev. Soc. Bras. Zoot. 21 (1992) 467-474.

[35] Van Straalen W.M., Odinga J.J., Mostert W., Digestion of feed amino acids in the rumen and small intestine of dairy cows measured with nylon bag techniques, Brit. J. Nutr. 77 (1997) 83-97.

[36] Varvikko T., Microbially corrected amino acid composition of rumen-undegraded feed protein and amino acid degradability in the rumen of feeds enclosed in nylon bags, Brit. J. Nutr. 56 (1986) 131-140.

[37] Wanderley R.C., Huber J.T., Wu Z., Pessarakli M., Fontes C. Jr., Influence of microbial colonisation of feed particles on determination of nitrogen degradability by in situ incubation, J. Anim Sci. 71 (1993) 3073-3077.

[38] Williams A.P., Recent developments in amino acid analysis, in: D'Mello J.P.F. (Ed.), Amino acids in farm animal nutrition, CAB International, Wallingford, UK, 1994, pp. 11-36. 